ich finansowo, po czym znikali ${ }^{1}$. Paweł świadomy możliwości posądzenia go o podobne intencje pracuje na swe utrzymanie. Najlepszym przykładem oskarżania apostoła o różne nieszczere intencje jest 2 Kor. $\mathrm{Z}$ jego Listów wynika, że nie korzysta $\mathrm{z}$ dóbr materialnych swych wspólnot, ponieważ nie jest przekonany o tym, że nie pojawią się zarzuty $^{2}$. Zwłaszcza Koryntianie byli gotowi wykorzystać każdą sposobność do tego, aby go krytykować. Jeżeli zatem apostoł korzysta ze wsparcia Filipian ${ }^{3}$, znaczy to, że jego relacje ze wspólnotą cechowało ogromne zaufanie; z kolei inicjatywa Filipian i ich poświęcenie dla Pawła, czy dla jego sprawy, świadczą o głębokiej więzi, jaka łączyła ich z apostołem. Na te relacje należy patrzeć do jakiegoś stopnia przez pryzmat roli kobiet w tamtejszej wspólnocie.

Dochodzimy do końcowego wniosku, że podstawowym wyróżnikiem kościoła w Filippi i jednocześnie jedną z racji (nie stwierdzamy, że jedyną) ogromnej troski Filipian o Pawła i ich ofiarności jest znacząca rola, jaką we wspólnocie odgrywały kobiety. Razem z tą rolą szła w parze znaczna pozycja materialna - przynajmniej niektórych z nich, jak Lidii. Wkład chrześcijanek z Filippi w pomoc Pawłowi przyczynił się w dużym stopniu do rozwoju ewangelizacji w ówczesnym świecie. Niniejszy przyczynek pragnie wydobyć ten fakt na światło dzienne i być względem nich skromnym wyrazem wdzięczności.

Lublin

KS. WALDEMAR RAKOCY CM

\title{
SKOWO TOWARZYSTWA BIBLIJNEGO W POLSCE NA ŚWIĘTO BIBLII 2002
}

„Ten, kto ma uszy niech usłyszy, co Duch mówi do Kościołów” (Ap 2, 7a).

W trudnej chwili swego życia nasz Pan dał nam wspaniały przykład postępowania. Poddany próbie, odwołuje się do Pisma Świętego, mówiąc: „Nie samym chlebem żyje człowiek, lecz każdym słowem,

${ }^{1}$ L. MorRIS, The First and the Second Epistles to the Thessalonians, NICNT, Grand Rapids 1991, s. 8-9.

${ }^{2} \mathrm{Z}$ tej racji być może nie chciał skorzystać z gościnności Lidii, której zaraz po jej nawróceniu nie znał dobrze, aby nie zostać posądzonym o nieszczere intencje.

${ }^{3} \mathrm{~W}$ jakimś stopniu również innych wspólnot (por. 2 Kor 11,8 ). 
które pochodzi z ust Boga" (Mt 4, 4). Jakże dziś w obliczu tylu prób i trudności potrzebujemy Bożej pomocy, Bożej rady, Bożego Słowa! I oto wspaniała wiadomość! Bóg nie zamilkł! „Żywe jest bowiem Słowo Boga i skuteczne, ostrzejsze niż wszelki miecz obosieczny" (Hbr 4, 12a). Jego Słowo nie przemija tak, jak nasze ludzkie sprawy i słowa, gdyż „Słowo Pana trwa na wieki” (1 P 2, 25a).

To Słowo Boże jest stale gotowe do nas przemawiać! Jak trafnie wyraził to znany kaznodzieja C. H. Spurgeon: „Nikt nie może powiedzieć, że mu brak źródła, z którego mógłby czerpać, jeżeli Biblia znajduje się w zasięgu jego ręki”. Czy możemy zatem powiedzieć, że nie mamy dostępu do Bożego Słowa? To niemożliwe! Przecież Pismo Święte jest najbardziej rozpowszechnioną i najpoczytniejszą księgą świata. To jest światowy bestseller! Dzięki Bożej łaskawości mamy w Polsce kolejne nowe thumaczenia Pisma Świętego, co pozwala każdemu z nas korzystać z mądrości Bożego Słowa. Ze szczególną radością należy przyjąć przekład ekumeniczny Nowego Testamentu i Psalmów. To nowe tłumaczenie pozwala nam, chrześcijanom różnych denominacji kościelnych, spotykać się przy jednym tekście Pisma Świętego.

Wykorzystajmy ten błogosławiony czas na wsłuchiwanie się w prorocze wezwanie Bożego Słowa: „Ten, kto ma uszy niech usłyszy, co Duch mówi do Kościołów" (Ap 2, 7a). Oto wezwanie Pana Chwały do Jego umiłowanego ludu - Kościoła. Ten jeden Kościół Jezusa Chrystusa opisany jest w Księdze Apokalipsy przez symboliczną liczbę siedmiu lokalnych kościołów. Kościół w swej istocie jest jeden, ponieważ jest jeden Pan, który nim kieruje i jeden Duch, który go ożywia i jednoczy w jedno Ciało $(1$ Kor 12, 13). To jedno Ciało Chrystusa uobecnia się na świecie przez lokalne społeczności, wspólnoty, zbory, parafie. Dlatego przeciwieństwem jednego Kościoła nie jest wielość i różnorodność wspólnot kościelnych, lecz Kościół błądzący, Kościół niewierny swemu Panu.

Pan Kościoła jak dobry pasterz nigdy nie pozostawi swojego Kościoła osamotnionego, lecz posyła swoje Słowo - chwali, karci, udziela nagany ale i składa obietnice. Czy mamy uszy gotowe, by wsłuchiwać się w słowa naszego Pana? On wzywa nas: „Obyś był zimny albo gorący" (Ap 3, 15b). Letnie chrześcijaństwo budzi odrazę w oczach Chrystusa: „Bądź gorliwy i nawróć się” (Ap 3, 19b). Dlatego na przykładzie kościoła w Filadelfii, Chrystus Pan poucza nas i wskazuje właściwą postawę chrześcijańską: „Znam twoje czyny. Oto sprawiam, że przed tobą są otwarte drzwi, których nikt nie może zamknąć, bo choć masz nie- 
wielką moc, to jednak zachowałeś Moje Słowo i nie wyparłeś się Mojego imienia" (Ap 3, 8). Kościół w Filadelfii zachowat, ale nie schowat Słowa Pana. Trwał przy prawdzie Jego Słowa i nie poszedł na kompromis, nawet za cenę odrzucenia i prześladowań.

Żyjemy w okresie wielkich przemian społecznych i kulturowych. Pluralizm i relatywizm staję się cechą otaczającego nas świata. Uwidacznia się to także w dziedzinie duchowego życia człowieka. Jak bardzo potrzebujemy dzisiaj pewnego i obiektywnego autorytetu w naszym życiu? A takim jest Słowo Boże! Jest dla wszystkich ludzi, a przy tym nie podlega jakimkolwiek ludzkim autorytetom. „Żadne stworzenie nie ukryje się przed Nim" (Hbr 4, 13a). Słowo przenika każdego, wszystkie Kościoły, gdyż nie jest zależne od naszych tradycji kościelnych. Oto w zmieniającym się świecie mamy pewny fundament - Słowa Bożego, które może dać każdemu z nas odpowiedź na zasadnicze i ostateczne pytania dotyczące sensu naszego życia.

Nie zamykajmy Księgi Pisma Świętego! W niej mówi do nas sam Bóg. Ten, kto ma uszy niech usłyszy co Duch mówi do Kościolów!

TOWARZYSTWO BIBLIJNE W POLSCE

\section{SPRA WOZDANIA I WIADOMOŚ C I}

\section{ks. Antoni Tronina}

\section{KATOLICKI KOMENTARZ DO STAREGO TESTAMENTU UWAGI METODOLOGICZNE}

Na spotkaniu zespołu biblistów w Warszawie 20 stycznia 2002 r. zapadła decyzja o potrzebie wydania nowego komentarza biblijnego o profilu naukowym. Prac nad redakcją tego dzieła, zakrojonego na wiele lat, podjął się komitet w składzie: R. Bartnicki (UKSW), T. Brzegowy (PAT), A. Paciorek (KUL), A. Tronina (KUL) oraz J. Warzecha (UKSW). Ks. prof. A. Paciorek - odpowiedzialny wespół z ks. rektorem Bartnickim za redakcję serii nowotestamentowej, przedstawił wówczas ogólne wytyczne dotyczące struktury komentarzy. Ponieważ jednak specyfika komentarzy do Starego i Nowego Testamentu 